\title{
SEMIOTIKA MASKULINITAS DAN FEMINITAS STUDI ATAS KONSTRUKSI GAYA HIDUP DAN IDENTITAS GENDER DALAM IKLAN
}

\author{
${ }^{1}$ Alifia Oktrina Fayardi, ${ }^{2}$ Abdul Firman Ashaf \\ ${ }^{1,}$ Magister Ilmu Komunikasi Universitas Indonesia \\ ,2Jurusan Ilmu Komunikasi FISIP Universitas Lampung \\ Email; ${ }^{2}$ ashafnov2008@gmail.com
}

\begin{abstract}
Lifestyle which attached to daily life has become a necessity for men and women. Lifestyle in advertisements often made the audience interested to follow it up. The audiences were made to consume products that were advertised to achieve the ideal lifestyle depicted in the ads. The aim of this study was to determine the lifestyle of men and women in men's product advertisements and women's product advertisements and also how the construction process. Methods and theories that were used in this study were semiotics of Roland Barthes. This study found that men's product advertisements emphasized men's lifestyle with masculine image. Women's product advertisements instilled women's lifestyle attached to appearances. Ads also brought new habits both for men and women as part of their lifestyle. Ads looked like to dictate people's lifestyles by providing an idea of how a person should look, what to eat, and how to spend leisure time.
\end{abstract}

Keywords: Advertisement, Lifestyle, and Semiotics.

\section{PENDAHULUAN}

Industri periklanan adalah industri yang berkembang sangat pesat. Hal ini dapat terlihat dari total belanja iklan terus meningkat dari tahun ke tahun. Berkembangnya industri periklanan membuat produsen iklan berlombalomba dalam mengemas pesan ke dalam bentuk yang menarik. Mereka dituntut untuk memahami tren, karakter dan minat khalayak serta memperhatikan segala unsur dalam iklannya agar pesan dapat menarik perhatian dan isinya akan tersampaikan dengan baik. Ada berbagai tema yang diangkat dalam sebuah iklan dan yang sering kita jumpai adalah iklan bertemakan gaya hidup. Gaya hidup sangat dekat dengan kehidupan sehari- hari sehingga lebih mudah jika digunakan dalam memepengaruhi pikiran khalayak.

Gaya hidup mencakup sekumpulan kebiasaan, pandangan dan pola-pola respons terhadap hidup, serta terutama perlengkapan untuk hidup. Cara berpakaian, cara kerja, pola konsumsi, bagaimana individu mengisi kesehariannya merupakan unsur-unsur yang membentuk gaya hidup (Suyanto, 2013: 138). Gaya hidup adalah bagian dari ciri masyarakat modern, terlebih masyarakat post-modern. Gaya hidup bukan hanya monopoli kaum perempuan, tetapi juga menjadi kebutuhan kaum laki-laki (Suyanto, 2013: 147). Kaum perempuan banyak tergoda dengan iklan yang berkaitan dengan kecantikan, seperti krim 
wajah, make up, minuman pelangsing, dan masih banyak lagi. Iklan-iklan produk tersebut membentuk gambaran ideal seorang perempuan pada pemikiran khalayak. Pada akhirnya, seringkali seseorang membeli produk yang sebenarnya tidak ia butuhkan tetapi semata-mata untuk mencapai kehidupan ideal yang tergambarkan dalam iklan. Bagi kaum laki-laki, saat ini telah banyak muncul iklan produk khusus untuk laki-laki yang menggunakan lebel "for men" pada kemasannya, salah satunya adalah pembersih wajah. Iklan produk khusus untuk laki-laki tersebut mengiklankan produknya dengan memanfaatkan citra maskulin dan hal-hal yang berkaitan dengan hobi, seperti olahraga dan musik. Iklan-iklan ini memunculkan gaya hidup baru bagi kaum laki-laki.

Iklan merupakan salah satu bentuk komunikasi massa yang tidak hanya berfungsi sebagai sarana promosi untuk menawarkan barang dan jasa saja, tetapi mengalami perluasan fungsi, yaitu menjadi alat untuk menanamkan makna simbolik melalui bahasa dan visualisasi dalam pesan iklan (Vera, 2014: 43). Iklan mewakili suatu makna tertentu yang oleh pembuatnya ingin disampaikan kepada khalayak sasaran, yakni kelompok tertentu dalam masyarakat (Hoed, 2014: 270). Terkadang pesan iklan dibuat sedemikian unik sebagai bentuk kreativitas pembuatnya, yang justru hanya berupa representasi dari suatu fenomena yang harus dimaknai oleh penonton atau pembaca iklan tersebut (Vera, 2014: 44).

Iklan adalah representasi kehidupan sehari-hari merupakan seperangkat tanda yang dapat dimaknai melalui semiotika. Semiotika itu sendiri menurut Umberto Eco (dalam Wibowo, 2013: 24) adalah teori dusta. Pada prinsinya (semiotika) adalah sebuah disiplin yang mempelajari segala sesuatu yang dapat digunakan untuk berdusta. Iklan menampilkan realitas semu di mana produk digambarkan sedemikian rupa dengan kesan dahsyat namun seolah tetap realistis. Pada akhirnya, konsumen akan percaya begitu saja tehadap kehebatan produk yang diiklankan.

Dalam penelitian ini, metode dan teori yang digunakan adalah semiotika Roland Barthes. Menurut semiologi Roland Barthes terdapat dua tahap penandaan atau bisa juga disebut signifikasi dua tahap. Denotasi merupakan signifikasi tingkat pertama, sementara konotasi merupakan tingkat kedua. Denotasi lebih diasosiasikan dengan ketutupan makna dan, dengan demikian, sensor atau represi politis. Mengikuti kerangka Barthes, konotasi identik dengan operasi ideologi, yang disebutnya sebagai 'mitos', dan berfungsi untuk mengungkapkan dan memberikan pembenaran bagi nilai-nilai dominan yang berlaku dalam suatu periode tertentu (Budiman dalam Sobur, 2013: 70-71). Dengan menggunakan metode semiotika Roland Barthes tersebut, penelitian ini bertujuan untuk 
Vol. 2 No.1 Agustus 2017

mengetahui gaya hidup laki-laki dalam iklan produk khusus untuk laki-laki, gaya hidup perempuan dalam iklan produk khusus untuk perempuan serta bagaimana proses konstruksinya.

\section{METODE PENELITIAN}

Penelitian ini menggunakan pendekatan kualitatif. Melalui penelitian ini, penulis memfokuskan penelitian pada adegan-adegan yang menggambarkan gaya hidup laki-laki pada iklan produk khusus untuk laki-laki (iklan Garnier Men Acno Fight, Rexona Men Invisible Dry, dan L-Men Gain Mass) dan gaya hidup perempuan pada iklan produk khusus untuk perempuan (Garnier Pure Active, Rexona Women Invisible Dry, dan WRP Limited Edition). Sumber data pada penelitian ini yaitu sumber data primer yang langsung dikumpulkan oleh peneliti dari sumber pertamanya yakni video iklan yang telah dipilih dari situs YouTube dan sumber data sekunder yang diperoleh dari dokumentasi dan berbagai literatur untuk mendukung penelitian. Teknik pengumpulan data menggunakan teknik dokumentasi dan studi pustaka. Teknik analisis data pada penelitian ini menggunakan tahap identifikasi tanda dengan memilih adegan yang berkaitan dengan gaya hidup, signifikasi dua tahap Roland Barthes untuk mengetahui makna denotasi dan konotasi iklan, dan pembahasan serta penarikan kesimpulan.

\section{HASIL}

Peneliti menemukan adegan yang menggambarkan gaya hidup laki-laki dan perempuan pada keenam iklan yang telah dipilih dengan menggunakan metode semiotika Roland Barthes. Pada iklan produk khusus untuk laki-laki, laki-laki digambarkan lekat dengan kehidupan perkotaan yang berpenampilan layaknya pria sukses, berpenampilan menarik, dan kerap mengisi waktu luang dengan berkumpul bersama teman, clubbing, serta berolahraga. Pada ketiga iklan produk khusus untuk laki-laki menampilkan kegiatan berolahraga, baik itu tinju ataupun basket. Olahraga digunakan untuk menekankan citra maskulin laki-laki karena olahraga dapat dimanfaatkan dalam memberikan gambaran mengenai laki-laki tangguh dan kuat.

Selain itu, iklan memunculkan kebiasaan baru bagi kaum laki-laki yaitu kebiasaan merawat diri. Laki-laki digambarkan menggunakan berbagai produk perawatan seperti busa pembersih wajah dan deodorant. Laki-laki yang merawat diri bukan berarti dia seperti perempuan tetapi dapat dianggap peduli terhadap dirinya sendiri. Perawatan diri yang dilakukan laki-laki menjadi hal yang wajar dengan adanya label 'for men' yang ada pada kemasan produknya.

Gaya hidup perempuan pada produk khusus untuk perempuan menggambarkan bahwa penampilan adalah hal utama yang 
Vol. 2 No.1 Agustus 2017

perlu diperhatikan. Iklan memberikan gambaran bahwa sosok ideal seorang perempuan adalah yang berwajah mulus dan bertubuh yang indah. Perempuan yang memiliki berbagai masalah pada wajah dan tubuhnya digambarkan sebagai sosok yang tidak bahagia. Perempuan kerap mengkonsumsi berbagai produk agar berpenampilan menarik dan itu menjadi bagian dari gaya hidup mereka. Selain itu, gambaran perempuan pada iklan produk khusus untuk perempuan berbeda dengan iklan produk lainnya yang umumnya menggambarkan perempuan lekat dengan urusan rumah tangga. Perempuan pada iklan produk khusus untuk perempuan digambarkan aktif berkegiatan di luar rumah dan mengisi waktu luang dengan melakukan olahraga, clubbing, berbelanja, dan bahkan melakukan latihan bela diri.

\section{PEMBAHASAN}

Iklan melalui media massa berusaha mempengaruhi khalayak agar terpikat dengan produk yang diiklankan dengan berbagai tanda yang digunakan. Iklan perlu melalui berbagai proses dan pertimbangan mengenai berbagai aspek pesan sebelum akhirnya dapat dipertontonkan. Media massa seperti halnya iklan di televisi adalah salah satu hal yang sangat berpengaruh dalam membentuk stereotype mengenai gaya hidup laki-laki maupun perempuan. Iklan memberikan contoh bagaimana seseorang berpenampilan, mengisi waktu luang, dan menjalani berbagai kegiatan di dalam hidupnya. Iklan yang telah membentuk identitas tertentu bagi kaum lakilaki dan perempuan akan mengkonstruksi gaya hidup laki-laki maupun perempuan.

Sesuai dengan pandangan kapitalisme yang meyakini bahwa pemilik modal dapat melakukan usaha untuk mendapatkan keuntungan sebesar-besarnya, iklan dimanfaatkan sedemikian rupa dalam meningkatkan keuntungan. Kekuatan dan dominasi kepentingan ideologi tertentu yang mendominasi media massa kita tentu sangat memprihatinkan. Terdapat dua kepentingan utama di balik media, yaitu kepentingan ekonomi (kapitalisme) dan kepentingan kekuasaan (politik). Kedua kepentingan itulah yang paling banyak menentukan dan membentuk isi media, informasi yang disajikan dan makna yang ditawarkan. Di antara dua kepentingan utama tersebut, ada kepentingan yang lebih utama yang justru terabaikan, yaitu kepentingan publik. Media yang seharusnya berperan sebagai ruang publik (public share), disebabkan oleh kepentingan-kepentingan di atas, justru mengabaikan kepentingan publik itu sendiri. (Yasir, 2012: 12).

Pada dasarnya iklan digunakan untuk membentuk suatu citra dan menjual produk yang diiklankan. Dengan banyaknya jumlah iklan yang bertebaran di media massa, produsen iklan berlomba-lomba mendapatkan 


\section{Vol. 2 No.1 Agustus 2017}

ide untuk mengemas iklannya agar tampak menarik. Berbagai tema dan citra digunakan sebagai komoditas produk yang diiklankan. Hal ini semata-mata untuk menanamkan ideologi kepada khalayak agar menggunakan produk mereka. Iklan memiliki kekuatan besar dalam membujuk khalayak dengan menanamkan hasrat untuk memenuhi kebutuhan semu.

Dalam era global seperti sekarang ini, media massa sendiri telah tumbuh menjadi informasi yang tidak hanya memenuhi kebutuhan masyarakat akan informasi, tetapi mengikuti standar dan logika yang hidup dalam industri budaya kapitalisme. Ia tak hanya memoles produk budaya, tetapi dengan produk budaya itu lantas mengkonstruksi selera, cita rasa, dan bawah sadar khalayak. (Ibrahim, dalam Suyanto, 2013: 118). Baik secara sadar ataupun tidak, informasi pada media massa seperti iklan perlahan dan terus menerus mempengaruhi pikiran khalayaknya. Iklan dengan segala kreatifitas copywriter dan visualiser menampilkan gambaran yang "wah" mengenai produknya tapi tetap dengan berusaha tampak normal dan se-realistis mungkin.

Di era masyarakat post-modern yang makin mengglobal, apa yang membuat kekuatan komersial mampu bertahan sesungguhnya merupakan kemampuan untuk memanipulasi emosi konsumen, menciptakan berbagai hyper-sign yang kreatif, dan kemampuan untuk mengembangkan dunia simulasi (Suyanto, 2013: 210). Ketika emosi khalayak dengan suatu produk terbentuk, maka akan sangat mudah bagi iklan untuk menarik khalayak agar segera mengkonsumsi produk tersebut. Citra produk yang dibangun sebuah iklan akan menarik perhatian khalayak terlepas dari apakah mereka benar-benar membutuhkan produk tersebut atau tidak. Gambaran luar biasa akan produk yang seolah dapat mengatasi masalah dengan mudahnya dalam waktu singkat membuat khalayak akan merasa membutuhkan produk tersebut dan tertarik akan kepraktisan yang ditawarkan oleh iklan.

Dalam konteks kapitalisme media, komoditi tidak lagi berfungsi sebagai objek utilitas, tetapi menjadi hyper comodity, yaitu komoditi yang menjadi ajang permainan semiotika status presentase, dan sensualitas komunikasi pemasaran (Andriani, 2011: 157). Menurut Umberto Eco (dalam Wibowo, 2013: 24), semiotika adalah teori dusta. Pada prinsinya (semiotika) adalah sebuah disiplin yang mempelajari segala sesuatu yang dapat digunakan untuk berdusta. Dalam perspektif semiologi, iklan disebut sebagai seperangkat tanda yang berfungsi menyampaikan sejumlah pesan (Kasiyan, dalam Widyatama, 2011: 27).

Dalam semiologi Roland Barthes terdapat dua tahap penandaan atau bisa juga disebut signifikasi dua tahap. Denotasi merupakan signifikasi tingkat pertama, sementara konotasi merupakan tingkat kedua. 


\section{Vol. 2 No.1 Agustus 2017}

Denotasi lebih diasosiasikan dengan ketutupan makna dan, dengan demikian, sensor atau represi politis (Budiman dalam Sobur, 2013:70). Seiring dengan pendapat tersebut, makna yang terlihat dalam iklan pada signifikasi tahap pertama seolah menutupi makna sebenarnya. Iklan tampak menampilkan masalah sehari-hari dan memberikan solusi dengan kehadiran produknya. Akan tetapi, lebih dari itu sebenarnya iklan menanamkan suatu hal yang lebih dalam ke dalam pikiran khalayak terutama dengan penyajiannya yang berulang-ulang. Selanjutnya, dalam kerangka Barthes, konotasi identik dengan operasi ideologi, yang disebutnya sebagai 'mitos', dan berfungsi untuk mengungkapkan dan memberikan pembenaran bagi nilai-nilai dominan yang berlaku dalam suatu periode tertentu (Budiman dalam Sobur, 2013:71).

Sebuah teks, kata Aart van Zoest tidak pernah lepas dari ideologi dan memiliki kemampuan untuk memanipulasi pembaca ke arah suatu ideologi (Wibowo, 2013: 23). Begitu pun dengan iklan yang dapat mengarahkan penontonnya ke arah suatu ideologi tertentu dengan berbagai tanda yang digunakan. Beberapa iklan yang berbeda dengan produk yang berbeda serta tema yang berbeda dapat menanamkan ideologi yang sama, misalnya iklan busa pembersih wajah, deodorant, dan minuman pelangsing. Ketiga iklan tersebut mengiklankan produk yang berbeda tapi sebenarnya mengarahkan pikiran khalayak kepada hal yang serupa, yakni bagaimana penampilan perempuan yang seharusnya. Ketiganya menggunakan narasi yang berbeda tetapi pada akhirnya menampilkan sosok perempuan 'sempurna' yang dapat dikatakan serupa, yakni berwajah mulus, bertubuh indah, rambut terawat, aktif, tampak bahagia. Bahkan iklan-iklan tersebut kerap juga menggambarkan perempuan yang berlawanan (berjerawat, bertubuh gemuk, rambut tak terawat) sebagai sosok yang muram dan tak bahagia.

Barthes memahami ideologi sebagai kesadaran palsu yang membuat orang hidup di dalam dunia yang imejiner dan ideal, meski realitas hidupnya yang sesungguhnya tidaklah demikian (Sobur, 2013:71). Ini juga yang terjadi dalam sebuah iklan, khalayak dibuat percaya dengan apa yang ditampilkan pada iklan dan dibiarkan larut hidup di dalamnya. Khalayak dibuat seolah mereka memiliki suatu kekurangan yang harus ditutupi dengan kehadiran sebuah produk dan selalu mengejar 'hidup yang ideal' yang sebenarkan takkan terwujud.

Tanda dalam iklan telah dirancang dan dibentuk sedemikian rupa untuk membentuk citra yang diharapkan dapat mempengaruhi khalayak. Tak jarang tanda-tanda yang ada pada iklan merupakan hasil rekayasa yang menampilkan realitas semu semata. Apa yang iklan tampilkan tentu saja tidak semuanya benar. Iklan menutupi satu sisi dengan 


\section{Vol. 2 No.1 Agustus 2017}

menonjolkan sisi lainnya. Seringkali iklan melebih-lebihkan kemampuan produknya seolah dalam sekejap produk tersebut dapat mengatasi suatu masalah.

Tanda-tanda dalam iklan mengacu pada suatu rencana konstruksi berisi positioning pada karakteristik konsumen tujuan. Untuk itu diperlukan suatu tampilan yang sesuai dengan karakteristik pasar ataupun produk. Ada dua jenis tampilan iklan: pertama, tampilan rasional (Rational appeals), ditunjukan pada kebutuhan fungsional dan praktis konsumen yang bisa didapat dari produk barang atau jasa. Kedua, tampilan emosional (emotional appeals) menggambarkan kebutuhan psikologis, yang simbolis yang dibutuhkan konsumen dari produk (William, dalam Wibowo, 2013: 156). Iklan dengan tampilan rasionalnya menampilkan produk serta kegunaannya, seperti deodorant untuk mengatasi masalah keringat, sabun mandi untuk menjaga kebersihan badan, dan lain sebagainya. Di sisi lain, iklan menggunakan tampilan emosional yang membuat khalayak merasa memiliki ikatan kuat dengan produk yang ditampilkan. Berbagai tema digunakan untuk memperkuat ikatan tersebut. Tampilan emosional disesuaikan dengan selera target khalayaknya dengan seolah menampilkan adanya kesamaan nasib antara tokoh iklan dan khalayak.

Pesan iklan yang dekat dengan konsumen tentu akan lebih diterima konsumen. Iklan dalam konstruksi pesannya berusaha menghadirkan figur-figur tertentu yang dekat dengan konsumen. Suharko mengatakan bahwa melalui iklan, citra mengenai kelompok-kelompok masyarakat tersebut dibentuk, didiktekan, dan dikonstruksikan ke dalam bangunan kesadaran yang bermuara pada bujukan untuk mengkonsumsi suatu komoditas (Wibowo, 2013: 154). Contoh pendekatan yang seringkali digunakan adalah gaya hidup karena gaya hidup dekat dengan kehidupan seharihari. Gaya hidup mencakup aspek yang luas dapat berupa cara berbicara dan bersikap, cara berpakaian, makanan yang dikonsumsi, barang yang digunakan, kegiatan yang dilakukan di waktu luang dan lain sebagainya.

Derasnya intensitas iklan televisi yang dilancarkan melalui media layar kaca, telah sedikit banyak mempengaruhi para pemirsa untuk mengikuti jejak dari ilustrasi yang telah mengobsesi para pemirsa lewat citraan produknya itu, demi mendapatkan tuntutan "gaya hidup" yang merupakan bagian penting dari kehidupan masyarakat modern. (Imanto, 2014). Gaya hidup yang ditampilkan dalam iklan merupakan suatu konstruksi sosial. Konsep gaya hidup dalam sebuah iklan sengaja dibentuk/dikonstruksi melalui berbagai bentuk interaksi yang melibatkan nilai-nilai yang berkembang di masyarakat.

Dalam iklan produk khusus untuk lakilaki, iklan kerap memanfaatkan stereotype 


\section{Vol. 2 No.1 Agustus 2017}

mengenai laki-laki yang dianggap dominan, kuat, serta aktif. Iklan seringkali menampilkan kegiatan fisik yang membutuhkan banyak energi dan lekat dengan citra maskulin seperti halnya olahraga. Maskulinitas itu sendiri adalah imaji kejantanan, ketangkasan, keperkasaan, keberanian untuk menantang bahaya, keuletan, keteguhan hati, hingga keringat yang menetes, otot laki-laki yang menyembul atau bagian tubuh tertentu dari kekuatan daya tarik laki-laki yang terlihat secara ekstrinsik (Kurnia, 2004: 22). Citra maskulin digunakan dalam iklan untuk menarik perhatian khalayak. Tokoh dalam iklan digambarkan seaktif dan sejantan mungkin untuk membentuk sosok ideal seorang laki-laki. Dalam kegiatan berolahraga, ketangkasan dan otot tokoh dalam sebuah iklan dapat digambarkan sedemikian rupa hebatnya dengan menggunakan berbagai teknik pengambilan gambar dan editing. Olahraga dapat digunakan dalam mengeksplor segala sisi maskulin seorang laki-laki.

Sedangkan pada iklan produk khusus untuk perempuan, masalah yang berkaitan dengan penampilan menjadi fokus utama. Perempuan memiliki hasrat lebih untuk tampil cantik dan memiliki tubuh ideal sehingga cenderung menjadi sasaran empuk bagi iklan. Dari sisi bisnis, perempuan Indonesia merupakan target potensial. Teks-teks iklan yang bertutur tentang kecantikan perempuan semuanya menunjukkan betapa kecantikan memiliki peran dan arti sangat penting bagi perempuan sendiri (Murwani, 2010: 13). Iklan seolah menggambarkan bahwa hidup akan lebih indah dan mudah jika memiliki penampilan yang menarik. Ingin tampil menarik bukanlah suatu kesalahan. Namun, defisini menarik yang ada di benak perempuan pengkonsumsi media adalah definisi yang memang sengaja dibentuk untuk menjual nilai dan produk yang ditampilkan.

Iklan kerap menggambarkan kegiatan masyarakat perkotaan, seperti olahraga, berbelanja, clubbing, dan berbagai kegiatan lainnya. Penampilan tokoh-tokoh iklannya pun memberikan kesan modern, di mana laki-laki terlihat bergaya dan perempuan yang kerap menggunakan pakaian tanpa lengan serta rok pendek.

Sejalan dengan perubahan dramatis selama akhir tahun 1990-an, hidup berubah, begitu juga konstruksi diri pada laki-laki. Mereka melakukan adaptasi terhadap feminism dan menawarkan konsep 'new masculinity' (Kurnia, 2004: 30). Muncul gambaran baru sosok laki-laki, yakni laki-laki metroseksual yang tampil dengan kekuatan dan kejantanannya tetapi memperhatikan penampilannya. Laki-laki metroseksual lekat dengan kehidupan perkotaan yang seringkali digambarkan dengan tubuh yang bagus terawat, kesuksesan, bergaya, dan banyak menghabiskan waktu luang di luar rumah, seperti kafe, gym, bahkan salon. 
Laki-laki metroseksual bukanlah lakilaki yang semata-mata seperti perempuan karena merawat dirinya. Merawat diri dianggap sebagai salah satu cara menyayangi dan menghargai diri sendiri. Jika dahulu lakilaki berpakaian rapi saja sudah cukup, saat ini media menggambarkan bahwa pakaian harus diperhatikan kesesuaiannya. Laki-laki perlu menggunakan parfum dan deodorant untuk menjaga aroma tubuhnya. Laki-laki juga digambarkan butuh membersihkan wajah dengan menggunakan busa pembersih untuk menjaga kebersihan. Semua itu merupakan hal yang sudah menjadi suatu kewajaran, terlebih lagi dengan adanya label "for men" yang menghiasi kemasan produk-produk tersebut. Dengan adanya label tersebut, anggapan bahwa laki-laki yang menggunakan produk perawatan menjadi seperti seorang perempuan akan musnah.

Perubahan gambaran tidak hanya terjadi pada sosok laki-laki tetapi juga pada sosok perempuan. Perempuan yang tadinya dianggap lekat dengan urusan rumah tangga terutama dapur menjadi perempuan modern yang berkarir serta banyak menghabiskan waktu di luar rumah. Dengan berbagai aktivitas yang ditampilkan dalam iklan, iklan seolah menciptakan kebutuhan baru dengan menekankan bahwa perempuan modern saat ini membutuhkan produk mereka.

Iklan mulai menampilkan kebiasaan yang dahulu masih dianggap tak wajar dilakukan seorang perempuan seperti kegiatan bela diri. Dengan menguatnya istilah emansipasi perempuan, berbeda dengan lakilaki yang merawat diri, perempuan justru mulai melakukan kegiatan yang dulu dianggap cukup keras, yakni bela diri. Latihan bela diri dilakukan dengan mengatasnamakan kesehatan dan dianggap bisa saja sewaktuwaktu memang dibutuhkan. Hal ini juga didukung dengan tersebarnya fasilitas untuk para perempuan untuk melakukan berbagai kegiatan yang dahulu dianggap tidak biasa.

Tak jarang dengan menggunakan gaya hidup sebagai pendekatan, iklan menghadirkan kebutuhan baru. Iklan akan selalu melontarkan masalah baru yang bisa diatasi dengan produknya kemudian nanti iklan akan memunculkan kembali masalah lain yang kembali dapat diselesaikan oleh produk dengan inovasi terbarunya. Siklus masalah dan solusi ini akan terus menerus berlangsung dan membuat konsumen merasa selalu memiliki masalah yang harus segera diatasi dengan produk yang diiklankan.

Tidak sedikit korban dari bujukan iklan televisi yang bisa mendarat dalam pikiran pemirsa hingga mereka rela merogoh kocek untuk membeli produknya, demi tuntutan mengikuti "gaya hidup" yang lagi ngetrend di tengah masyarakat, sebagai hasil pengaruh lansiran dari iklan televisi (Imanto, 2014). Bahkan seringkali untuk mengikuti gaya hidup tersebut, seseorang bisa mengeluarkan biaya 


\section{Vol. 2 No.1 Agustus 2017}

yang tidak sedikit. Mereka hanya melihat nilai suatu produk dan berbelanja didasarkan hasrat semata bahkan seringkali tanpa mempertimbangkan kondisi keuangan mereka.

Gaya hidup yang ditampilkan iklan dapat membentuk budaya baru pada masyarakat. Salah satunya adalah budaya yang biasa disebut budaya pop. Budaya pop pada dasarnya merupakan budaya yang menyenangkan dan banyak disukai orang karena citranya yang menghibur, menyenangkan, dan mampu mengembangkan imajinasi. Sebagai bagian dari budaya massa, budaya pop acap kali dianggap sebagai dunia impian kolektif, memberi ruang bagi eskapisme yang bukan hanya lari dari atau ke tempat tertentu, tetapi pelarian utopia kita sendiri (Suyanto, 2013: 119). Seseorang yang sibuk dan penat akan rutinitasnya membutuhkan suatu hiburan untuk "lari" dari rutinitasnya tersebut. Iklan menampilkan berbagai macam pilihan kesenangan untuk dapat dijalani, seperti olahraga, berkumpul dengan teman di kafe, berbelanja, dan clubbing. Kegiatan tersebut dikemas sedemikian rupa sehingga tampak begitu mengasikan dan dapat dijadikan pilihan oleh mereka yang penat. Menggunakan uang untuk menghibur diri sendiri merupakan hal yang wajar, tetapi akan menjadi salah jika kita menggunakan alasan itu semata-mata untuk mengikuti gaya hidup yang sebenarnya tak perlu tetapi tampak mengasikan tersebut secara berlebihan yang justru menciptakan budaya konsumtif.

Gaya hidup yang ditampilkan dalam iklan tampak begitu keren dan mengasyikan. Iklan seolah mendikte bahwa inilah gambaran gaya hidup yang sebenarnya dan inilah yang menjadi acuan dalam bertindak. Sehingga mendorong seseorang untuk mengikuti segala macam konten yang ditampilkan dalam iklan, mulai dari cara berpenampilan, apa saja yang harus dikonsumsi, bagaimana kita bersikap, dan lain sebagainya. Hal ini membuat seseorang ingin menjalani hidup seideal yang digambarkan oleh iklan dengan melalui berbagai cara yang bahkan di luar kemampuannya.

Akan tetapi, seperti apapun iklan menggempur khalayak dengan menggambarkan suatu realitas dengan begitu dahsyatnya, khalayak tetap dapat memberikan kontrol terhadap tindakan yang akan dilakukan selanjutnya. Stuart Hall menjabarkan metode encoding-decoding untuk mengintepretasikan persepsi khalayak yang mana keduanya merupakan proses pemaknaan. Proses pemaknaan pesan ini dipengaruhi oleh 3 unsur yaitu kerangka pengetahuan (frameworks of knowledge), relasi produksi (relations of production), dan infrastruktur teknis (technical infrastructure) yang memungkinkan adanya perbedaan antara encoding dan decoding. Untuk itu, Stuart Hall membagi tiga tipe utama pemaknaan atau pembacaan khalayak terhadap 


\section{Vol. 2 No.1 Agustus 2017}

teks media, yakni dominant reading, negotiated meaning, dan oppositional decoding (Baran, 2010: 270). Jadi, sebenarnya khalayak bisa saja tidak serta merta mengikuti semua yang didiktekan iklan. Jika khalayak sadar apa yang sebenarnya diusahakan iklan untuk disampaikan, khalayak dapat mengambil kontrol untuk menerima begitu saja dan mengikutinya (dominan reading), menegosiasikan dan memilah-milah apa yang perlu untuk diikuti dan apa yang tidak (negotiated meaning), atau justru menolah mentah-mentah gagasan yang disampaikan oleh iklan tersebut (oppositional decoding).

Hal yang perlu diingat adalah bahwa khalayak banyak hanya sekedar menjadi "konsumen" pesan media komunikasi yang pasif, padahal seharusnya mereka menjadi individu yang aktif dalam negosiasi makna pesan yang disampaikan. Tayangan televisi akan dimaknai berbeda oleh yang cerdas dan melek media bila dibandingkan dengan masyarakat yang cenderung umumnya lebih banyak pasif. Jika ada dua orang yang melihat sesuatu realitas sosial yang sama, atau membaca ayat dari suatu kitab suci yang sama, akan menghasilkan pandangan, penilaian, sikap dan perilaku yang berbeda pula. Perbedaan ini semuanya dikarenakan perbedaan paradigm yang dimiliki, yang secara otomatis memengaruhi persepsi dan tindak komunikasi seseorang. (Yasir, 2012: 910). Begitu juga halnya dengan iklan, ketika khalayak sadar akan apa yang ditanamkan oleh media, mereka bisa memberikan kontrol kepada dirinya untuk tidak serta merta mengikuti gaya hidup dalam iklan dengan begitu saja karena gaya hidup dengan berbagai kemudahan yang digambarkan dalam iklan bukanlah realitas sebenarnya.

\section{KESIMPULAN}

Dari penjabaran terkait penelitian ini, maka dapat disimpulkan beberapa hal sebagai berikut:

1. Iklan produk khusus laki-laki seringkali menampilkan adegan yang berkaitan dengan fisik seperti olahraga untuk menekankan citra maskulin. Iklan juga menciptakan kebutuhan baru bagi lakilaki yang kini telah menjadi gaya hidup, seperti perlunya mengkonsumsi suplemen untuk menambah massa otot dan perlunya merawat diri. Dengan adanya label "for men" pada kemasan produk perawatan, akan wajar bagi lakilaki untuk menggunakan produk tersebut tanpa mengurangi sisi maskulin mereka. Iklan juga kerap menggambarkan lakilaki metroseksual yang lekat dengan gaya hidup metropolis dengan berbagai aktivitas olahraga, baik indoor maupun outdoor, dan clubbing.

2. Iklan produk khusus perempuan kerap menanamlan bahwa penampilan merupakan hal utama. Kecantikan 


\section{Vol. 2 No.1 Agustus 2017}

seorang perempuan yang digambarkan dalam iklan begitu sempurna membuat perempuan merasa tak pernah puas dan ingin menggunakan berbagai produk perawatan serta mengkonsumsi berbagai produk yang diiklankan. Selain itu, gambaran perempuan mulai bergeser dari lekat dengan urusan rumah tangga menjadi perempuan modern yang bekerja, menghabiskan waktu di luar rumah, dan memiliki keinginan untuk menikmati hidup. Iklan menampilkan berbagai kegiatan yang dapat menjadi pilihan bagi perempuan seperti berolahraga, menari, clubbing, berbelanja, bahkan melakukan latihan bela diri.

3. Dengan berbagai tanda yang ditampilan, iklan seolah mendiktekan gaya hidup masyarakat dengan memberikan gambaran bagaimana seseorang harus berpenampilan, apa yang perlu dikonsumsi, bagaimana cara mengisi waktu luang, dan lain-lain. Iklan seringkali menggambarkan kemampuan produknya yang seolah-olah begitu dahsyat tetapi dikemas serealistis mungkin. Iklan juga selalu memunculkan kebutuhan baru bagi masyarakat. Apa yang telah dikonsumsi selama ini seolah tidaklah cukup, iklan terus menerus menampilkan masalah baru dengan produk mereka sebagai solusinya.
Produk yang diiklankan seakan begitu penting dan harus dimiliki. Tak jarang seseorang menjadi konsumtif dan membeli barang tanpa bisa membedakan mana produk yang memang dibutuhkan dan mana yang tidak.

\section{DAFTAR PUSTAKA}

Andriani , Tuti. 2011, "Media Massa dan Konstruksi Gaya Hidup Perempuan", Jurnal Marwah Universitas Islam Negeri Sultan Syarif Kasim, Pusat Studi Gender dan Anak Volume 10 Nomor 2.

Baran, J \& Dennis K. Davis. 2010. Teori

Komunikasi Massa: Dasar, Pergolakan dan Masa Depan, , Jakarta: Salemba Humanika

Hoed, Benny H., 2014. Semiotik \& Dinamika Sosial Budaya. Depok: Komunitas Bambu.

Imanto, Teguh. Pengaruh Iklan Televisi dalam Pencitraan Gaya Hidup. 20 Desember 2014.

http://www.esaunggul.ac.id/article/penga ruh-iklan-televisi-dalam-pencitraangaya-hidup/

Kurnia, Novi. 2004. "Representasi Masklinitas dalam Iklan”, Jurnal Ilmu Sosial dan Ilmu Politik Volume 8, Nomor 1, Juli 2004.

Murwani, Endah. 2010. “Konstruksi 'Bentuk Tubuh Perempuan' Dalam Iklan Televisi”, Jurnal Ilmu Komunikasi, Volume II, Nomor 1, Juni 2010.

Sobur, Alex. 2013. Semiotika Komunikasi, Bandung: Remaja Rosdakarya. 
Commed : Jurnal Komunikasi dan Media

Vol. 2 No.1 Agustus 2017

Suyanto, Bagong. 2013. Sosiologi Ekonomi:

Kapitalisme dan Konsumsi di Era

Masyarakat Post-Modernisme. Jakarta:

Kencana Prenada Media Group.

Vera, Nawiroh. 2014. Semiotika dalam Riset Komunikasi. Bogor: Ghalia Indonesia.

Wibowo, Indiwan Seto Wahyu. 2013.

Semiotika Komunikasi. Jakarta: Mitra

Wacana Media.

Widyatama, Rendra. 2011. Teknik Menulis

Naskah Iklan. Yogyakarta: Cakrawala.

Yasir. 2012. "Paradigma Komunikasi Kritis:

Suatu Alternatif Bagi Ilmu Komunikasi”,

Jurnal Ilmu Komunikasi Vol 1, No 01

(2012). 